\title{
When the Corporation Almost Displaced the Entrepreneur: Rethinking the Political Economy of Research and Development
}

\author{
MARGARET B. W. GRAHAM
}

In 1988 I had the dubious distinction of being billed "The World's Expert on Failure” in the South Korean press. This headline came about when I shared the findings from my book on the RCA VideoDisc with the top hundred or so executives and staff members of Samsung Electronics. They were engaged in the strategic planning exercise that would mark Samsung's explosive entrance onto the international stage, as local host of the Olympics and as exporter of consumer electronics. I think you can see from the picture of me addressing the Samsung vice presidents and senior staffs that I could only wonder what the translator was making of what I had to say.

Following this year's Business History Conference's theme of Reinterpretation, I want to revisit that work on the business of R\&D at Radio Corporation of America (RCA) and add a parallel account of the origins of advanced research at Xerox to offer some perspective on the rise and fall of corporate research, the institutionalized form

(c) The Author 2017. Published by Cambridge University Press on behalf of the Business History Conference.

doi:10.1017/eso.2017.5

Published online April 3, 2017

Margaret B. W. Graham is a professor of Strategy and Organization at the Desautels Faculty of Management, McGill University. She holds an MBA and a PhD from Harvard University. Before joining McGill, she served on the faculties of the Harvard Graduate School of Business Administration and the Boston University School of Management. She was a founding director of Winthrop Group Inc., a firm specializing in History and Information Services. She also served four years on the senior staff of the Xerox Palo Alto Research Center. Since 1990 she has been a fund trustee of Pioneer Investments, an investment company owned by the Italian bank Unicredito. In 2016 she served as president of the Business History Conference meeting in Portland, Oregon. E-mail: margaret.graham@mcgill.ca.

I want to acknowledge Patrick Fridenson, Richard R. John, Louis Galambos, William Becker, Naomi Lamoreaux, Kenneth Lipartito, Mary O’Sullivan, David Hounshell, Andrew Russell, Eric Hintz, and Lee Vinsel, whose comments or scholarship, or both, have contributed to this presidential address. At least half of them might take issue with my reinterpretation, but all of them have given me much to think about, and I thank them for their wonderful and enduring work. 


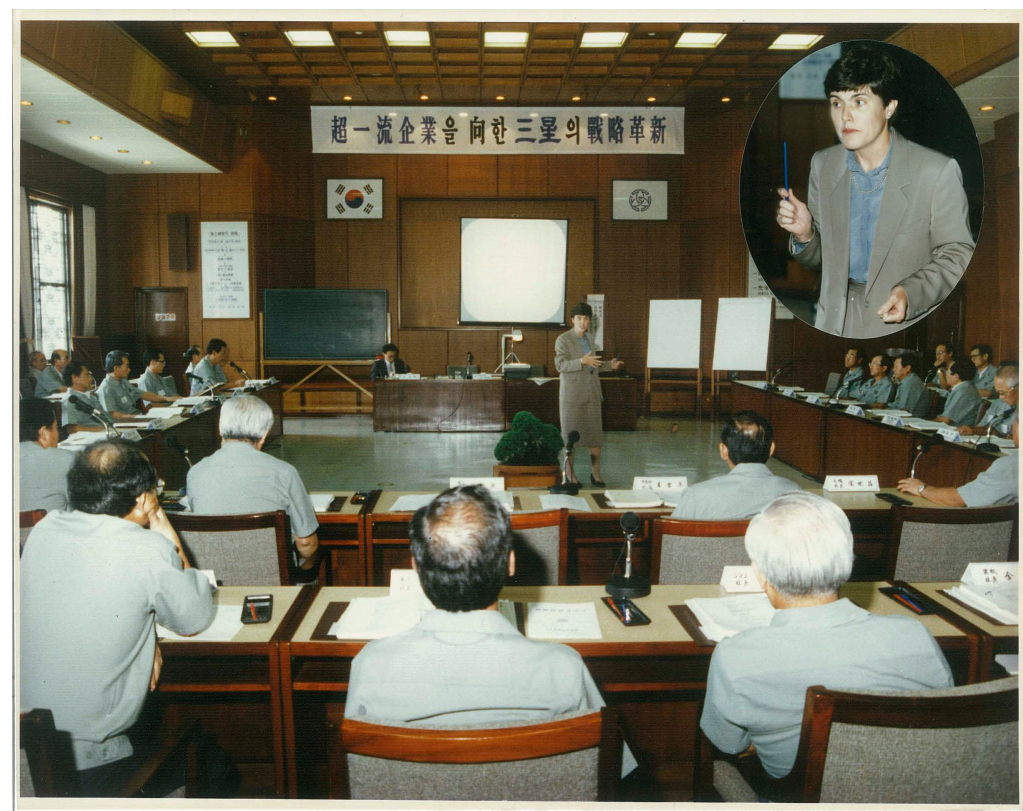

Figure 1 Author addressing Samsung Electronics Strategy Meeting. Source: Courtesy of Samsung Electronics. Photograph sent to the author as a memento of the Strategy Meeting.

of industrial research. ${ }^{1}$ This is a personal perspective aiming to raise questions that are pointed at, but not resolved, in more recent research. Many of the sources that might support what are suggestions on my part are still classified or fall into the category of privileged communication between counsellor and client. Corporate research has dropped out of sight as a topic in the last decade or so, but it is likely to reemerge in the twentieth-first century as companies like Apple and Google build huge secretive research campuses in Silicon Valley and set up satellite research laboratories in many countries. ${ }^{2}$ I believe that there are lessons to be learned from the earlier work on this topic that are important not

1. Graham, "Industrial Research in the Age of Big Science"; Graham, RCA and the VideoDisc; Graham and Pruitt, R\&D for Industry; Graham and Shuldiner, Corning and the Craft of Innovation.

2. Graham, "Transformation of Corporate Research," which was published shortly before the Korean experience, predicted that if corporate R\&D disappeared, it would have to be reinvented. Google's "Moonshot" strategy for its new holding company, Alphabet, and Apple's huge and secretive new campus in Silicon Valley, and the rising tendency of these firms and others like them to buy up smaller inventive firms rather than leave them out in the open suggest that an era of corporate enclosure may be under way again. The year 2016 broke records for IPOS and for mergers and acquisitions of this type. 
only for what we took into account but also for what we overlooked. ${ }^{3}$ Once I might have viewed RCA as unparalleled in its mismanagement of innovation, but when I consider the shifts in the political economy for R\&D that took place in the latter part of the twentieth century, I realize that RCA's difficulties were not entirely of its own making. My title alludes to Joseph Schumpeter's prediction that the large industrial laboratory would eventually displace the entrepreneur as the dynamic element in the twentieth-century economy. For decades it looked as though Schumpeter was right, but by the late 1980s, I and other interested observers were noting the decline of the corporate laboratory as a dynamic institution and a resurgence of entrepreneurial activity was once again visible in the wild. ${ }^{4}$

The time I spent at Samsung during its strategic planning exercise in the run-up to the Seoul Olympics gave me a ringside seat for what would prove to be a breakout for the company. ${ }^{5}$ My first book, RCA and the VideoDisc: The Business of Research, had been published in 1986, only months after RCA had been absorbed by General Electric and only a couple of years after the VideoDisc had failed in the marketplace. The book was unusual in telling an inside story that led to a highly visible business failure. ${ }^{6}$ Samsung's planners wanted to know more about the demise of RCA because they regarded the pioneering consumer electronics company as an important

3. Reich, Making of American Industrial Research; Hounshell and Smith, Science and Corporate Strategy; Lipartito, "Picturephone." Significantly, Jenkins, in Images of Enterprise, did not mention R\&D. According to Eastman-Kodak's first research director, Kenneth Mees, George Eastman set up a central laboratory in 1912 only because he felt his company was being unfavorably compared to German chemical companies for not having a serious research program. Clark, "Charles Edward Kenneth Mees."

4. Graham, "Transformation of Corporate Research"; Rosenbloom and Spencer, "Introduction," in Engines of Innovation.

5. The strategic planning expert who advised the strategic planning meeting at Samsung was Lowell Steele, a recently retired R\&D executive from GE, who had been a valued member of its widely respected strategic planning process. In 1987 Samsung opened a central laboratory, and in 1988 it merged its telecommunications and electronics companies and set the goal of being one of the top five electronics companies in the world. Today, Samsung Group is one of South Korea's leading chaebol, the family-controlled conglomerates that include heavy industry, biotech companies, and skyscraper construction, along with subsidiaries in many other industries. As I write, Samsung's CEO (Mr. Lee's son) has been appearing in front of the country's parliament with other heads of Korean chaebol to answer questions about the covert connections between the leading companies and the country's government. See Sang-Hun and Mozur, "Samsung Galaxy Note 7 Crisis Signals Problems at Korea, Inc.," and stories cited therein.

6. In his Business History Conference Presidential Address in 2005, Patrick Fridensen pointed to this study of failure as something business historians should do more often. I agree, and wish I could claim to have done it deliberately. Business historians have been timid in their critical assessments of American business. I do not know enough to level the same charge at historians in other countries. 
forerunner to their own. Many, not knowing the murky story of the merger/acquisition by General Electric that followed, believed VideoDisc had sunk the company. ${ }^{7}$ Why had this project been allowed to become such a spectacular failure? Mr. Lee Kun-Hee, who had just succeeded his father, Lee Byung-Chull, the founder, as chairman and CEO of Samsung, no doubt recognized some disturbing parallels between his family company and RCA. ${ }^{8}$ By exposing Samsung's top several hundred managers to RCA's story, he hoped to avoid any foreseeable pitfalls.

The invitation to share my interpretation of the RCA story was not only an opportunity but also a dilemma. My research at RCA, extensive though it had been at the Sarnoff Laboratories in Princeton and at RCA's headquarters at 30 Rockefeller Center, as well as interviews with former employees, had never been intended to explain failure. The study, which began in 1976, was an attempt to open the "Black Box." We wanted to know how large companies organized themselves to innovate, and we had the chance to study this big "bet-the-company" project of RCA's on the inside, partly in real time. ${ }^{9}$ My research in the company ended before VideoDisc went to market in the early 1980s. Though the project had been much delayed, no one thought it would fail completely. Much less could I imagine that this still large and important company could be weakened to the point that General Electric would absorb it, or even that GE would be allowed to make the acquisition without opposition from the

7. A comprehensive treatment of the murky inside story appeared in the New York Times (see Davis, "Did RCA Have to Be Sold?”; Davis was also a contributing editor of Harper's Magazine.) It was based on interviews with many disgruntled RCA insiders, only a few of whom were named in the story.

8. The obvious parallels Mr. Lee would have seen: father-son succession and being the largest consumer electronics company in its country. Since the delivery of this presidential address, more extended parallels have come to light around the next generation's succession to leadership. In October 2016, Samsung Electronics, which had been extremely successful in the international smartphone market, rushed its latest version, Samsung Note 7, into the marketplace to anticipate the arrival of Apple's iPhone 7, much the way RCA had rushed VideoDisc development in response to the Philips optical version of a video player. A company that had been scrupulous in its risk management around earlier Galaxy models, to the point of smashing whole piles of them when small defects were discovered, released a phone that burst into flames and was banned from airplanes, after which the company was reported to have botched its recall. In late November, Samsung announced it would yield to investor demands to restructure the company to release more value for the shareholders. There has been speculation that a contributing factor in the company's "botched recall" was the South Korean government's customary deferential treatment of Samsung, even in matters involving consumer safety.

9. Opening the "Black Box" is a reference to the work of economic historian Nathan Rosenberg, who pushed economists to recognize that technological innovation had become a process endogenous to the corporation and worthy of more careful study. See Rosenberg, Exploring the Black Box. 
U.S. Justice Department. ${ }^{10}$ RCA still had a respected brand, deep research capabilities, and valuable intellectual property. Many believed the business had been turned around under the leadership of Thornton Bradshaw and Robert Fredericks. Though suffering from Japanese competition, RCA was still the leading U.S. consumer electronics company. It had important government business, the prospects for which were improving under the Reagan administration. Mr. Lee wanted to know why VideoDisc had failed. I was uncomfortable with the only explanations that I thought applied beyond RCA: they contradicted prevalent ideas about big business.

My history and others like it focused mainly on managerial decision making inside the firm. Perhaps because our research was aimed at showing how innovation had become endogenous to the corporation, we paid less attention to changes in RCA's business environment, and mostly took the political environment for granted. In my account, VideoDisc had suffered from fierce escalating internal competition among RCA divisions, fuelled in part by the central laboratory's growing insistence on promoting its proprietary technology to ensure its own funding. VideoDisc was the last in a long series of research-based projects at RCA that had ended in failure. At the time, this explanation seemed to fly in the face of Chandlerian doctrine. In my rendering, RCA's VideoDisc had failed because of the very things that Alfred Chandler had promoted as the secret to the success of the American corporation: the "M-Form" hierarchy incorporating corporate research, supporting strategic diversification, and led by professional management. ${ }^{11}$

10. Given the importance of RCA's entertainment and technology holdings, GE's takeover of RCA would have been a natural target of antitrust action less than a decade earlier, but after 1980 the Reagan administration had pivoted on antitrust enforcement, as advised by proponents of big business and laissez-faire policies like those of Robert Bork, the controversial legal scholar whose nomination by Richard Nixon to the U.S. Supreme Court had earlier been rejected in a messy congressional fight.

11. Chandler, Visible Hand. See also John, book review of Problem of Remaining Innovative, in Business History Review. When I published RCA VideoDisc, Chandler had not yet extended his work into the post-World War II era. The argument that promoting R\&D within the organization was a masterful organizational innovation leading to learning pathways and innovation routines was the interpretation that Chandler would introduce in Scale and Scope and develop further in his last work, advancing into the postwar twentieth century, Inventing the Electronic Century. Chandler arrived at the conclusion that RCA's downfall was adopting two strategies at the same time: attempting to enter the nondefense computer industry against IBM and diversifying into a conglomerate form. The justification given was that the consumer goods company would throw off the cash needed to fund the new computer business. Chandler barely mentioned either RCA's aggressive licensing of its leading-edge technologies to the Japanese or the U.S. government's role in pushing for unrelated diversification in leading American companies. Chandler, Inventing the Electronic Century. 
Neither Chandler's professional managers nor his M-Form were like those I encountered at RCA. There, the "whiz kids" hired from Ford and IBM were confident that their analytic methodologies applied to everything - and the M-Form had blossomed into the conglomerate, embracing all sorts of businesses that had practically no synergies, though still including a sizable piece that was especially important to the laboratory: the military and government business. My book highlighted the inability of the corporate laboratory, once tasked with being the technological entrepreneur, to gain the cooperation of the several other divisions that were key to the VideoDisc's success. I also stressed RCA's pattern of making its technological choices based on returns to intellectual property rather than on dealer or consumer preference, or even on its ability to manufacture the product. I could not comment on other reasons for failure. I had no idea whether RCA was typical of other large technology-based companies or not, and had little knowledge of whether changing conditions in the political and business environments had affected their strategies. The business press, a small journalistic niche at the time, treated RCA as a uniquely bungled case.

There was, I would discover later, more about the way corporate research had evolved after World War II that shaped projects like RCA's VideoDisc in other companies and in other industries as well. One change was the trend toward greater professionalism in management and a growing impatience with an entrepreneurial style of leadership. A mental disconnect arose between the research community and senior management, increasingly staffed not by entrepreneurial engineers, as it often was in the immediate postwar era, but by lawyers, accountants, and marketing specialists. In the struggle for control among the various professions that had been taken into the corporation, scientists were running into opposition. ${ }^{12}$ The growth of executive powers in the federal government made the advice of legal counsel more important, causing companies to be more risk-averse in their approach to financing innovation and narrower in their valuation of performance. Corporate laboratories were getting more public recognition for their contributions to science than for their contributions to their companies. ${ }^{13}$ The postwar emphasis on scale was driving up the costs of R\&D. Even in research, the need for large equipment

12. In Graham, "Intellectual Property and the Professionals," I discuss the early phases of this struggle for control of the corporation. The piece argues that the scientists and lawyers working inside the corporation shared common interests before World War II, but that their interests diverged after the war, with lawyers gradually gaining the upper hand. See also Lipartito and Miranti, "Professions and Organizations in 20th Century America."

13. Lipartito, book review of After the Breakup, in Business History Review. 
and massive test facilities increased the ultimate risk of technologybased innovation. The need to propose large projects that justified such expense and would visibly register on the bottom line led to the "blockbuster," betting the company on untried and highly uncertain technologies, leading to colossal product failures. In short, concurrent with the loss of entrepreneurial leadership came disenchantment with the laboratory as innovating entrepreneur. ${ }^{14}$

Critics of historical studies of innovation have pointed out that these studies have short-changed the political economy of innovation After absorbing the work of colleagues and getting to know six or seven other corporate research centers, I could not help but concur. Huge increases in government funding tended to mask other shifts in the political economy and its institutional context-including the evolution of important institutions like antitrust enforcement and patent policy. This problem was exacerbated by the classified status of the sources in the Cold War era. But so much intriguing work has now been done in related areas that it may be possible to read between the lines. ${ }^{15}$

Corporate research was the form of industrial research that for several decades, starting in the interwar period, was adopted by many U.S. corporations as the substitute for the dynamic, but unprofessional, qualities of the entrepreneur. My title, "When the Corporation Almost Displaced the Entrepreneur," refers to the mid-twentieth-century period in the United States-1938 to 1978-a period known for its pattern of "closed innovation."16 The first part of the essay covers

14. Florida and Kenney, Breakthrough Illusion; see Rosenbloom and Spencer, Engines of Innovation, in which current and former research directors from several leading research-performing companies-IBM, Xerox, Alcoa, Intel-in their respective industries reflect on U.S. industrial research at the end of an era. See also Lipartito, "Picturephone." Shane Greenstein catalogs similar problems of large federally funded projects in the public sector, which were beset with numerous problems of political interference and conflicts of interest. Greenstein, How the Internet Became Commercial, 72.

15. One would expect the Political Economy of Innovation during the Cold War, mostly in technology-based businesses, to be covered by historical research on the Military Industrial Context. Judging from Alex Roland's AHA handbook on the Military Industrial Complex, however, little has been said about government-funded R\&D in businesses that were not mainly defense contractors, in which military hardware and systems were not the chief or only focus of the business. Roland, Military-Industrial Complex.

16. See John, "Patents and Free Enterprise." As the Temporary National Economic Committee experts concluded from their investigations, the corporation had been enclosing technology and accumulating intellectual property during much of the twentieth century. To those conducting the monopoly hearings, it was an outrage that government and the courts had been effectively defending corporate technical monopolies that were using their patent holdings to organize industries and to suppress competition. See Wells, Antitrust and the Formation of the 
the transformation of industrial research into corporate research, begun before World War II and accelerated by it. I have argued elsewhere that the role and function of corporate research as central to technology-based innovation was profoundly altered by the rise of the "Warfare State" as the research center was enlisted into the first line of defense in the Cold War. ${ }^{17}$ The effect of Big Science and the Military Industrial Complex on industrial research has been addressed before, but recent scholarship casts a new and interesting light on the ongoing confrontation between military and civilian science. This work draws attention, among other things, to the differences in military and civilian styles of management, which especially affected innovation supported by various branches of the military. ${ }^{18}$ On the civilian side, the changes in two other interrelated institutions, antitrust policy and intellectual property protection, deserve more attention for the way they directly and indirectly affected the way corporate research functioned to support, or undermine, innovation.

In the second part of this essay I examine the consequences of this wartime institutional transformation for two corporate laboratories, both of which supported a mix of private and government business and which received funding from both sources. I treat these establishments as bookends for the mid-twentieth-century period, typically regarded as the heyday of industrial research: RCA Laboratories, the preeminent laboratory focused exclusively on electronics research, and Xerox Palo Alto Research Center (PARC), a leading center for nascent computer science and solid state physics, which opened a generation after RCA Laboratories. These research centers, prominent in their own day, continued to be recognized as two of the most distinguished advanced research centers in the United States long after the corporations themselves had ceased to be regarded as innovators. In 1997 Fortune Magazine referred to them as two of a small group of laboratories that it called the U.S. Brain Trust. ${ }^{19}$

Postwar World; see also Lipartito, "Antimonopoly Tradition," which draws on the enforcement action against Western Electric to show that even though no break-up occurred in many of the cases brought in the 1950s, the experience of antimonopoly prosecution and settlement for AT\&T and others brought about more socially responsible behavior, including $\mathrm{R} \& \mathrm{D}$ efforts that were not necessarily expected to pay off.

17. Graham, "When Industrial R\&R Became Corporate." See also Sparrow, Warfare State; Wilson, book review of Warfare State, in Enterprise and Society.

18. Galison and Hevly, Big Science; see references in the masterwork on wartime procurement, Koistinen, Arsenal of World War II (but see n22, below).

19. Fortune Magazine, "Brain Trusts.” The article lists Bell, Sarnoff, IBM, and Xerox PARC, all then still operating, in that order. Sarnoff Corporation employed 600 of its more than 850 employees in what it termed basic research, and PARC employed 240 of its 340 employees in basic research. Bell Labs reported 4,000 of its 24,000, and IBM would not divulge its advanced research numbers. 


\section{Corporate Research Institutionalized}

Conventional wisdom holds that corporate research, as a form of industrial research that opened new strategic directions for the corporation, originated in the United States with the founding of General Electric's research laboratory in $1900 .{ }^{20}$ Before World War I, several "pioneering" research laboratories were founded, but the pattern of innovation for the most part relied on an open market for scientific and technical knowledge. ${ }^{21}$ Most American companies that needed scientific expertise drew on university professors, hired professional engineers to problem-solve their processes, and relied on independent inventors for new product ideas. Those that did establish industrial research laboratories realized benefits both from the interdisciplinary collaboration and from close cooperation among laboratory and production site, inventors, engineers, and scientists. After World War I, when Germany demonstrated the horrifying value of science-based research for military purposes, and when U.S. companies needed to replace specialized equipment and materials formerly sourced from German companies, many more U.S. companies established research laboratories funded primarily by private money. ${ }^{22}$ Government funding for research went to government laboratories usually at arsenals and to organizations such as the Naval Research Station and the Geophysical Laboratory. ${ }^{23}$ Only in isolated cases did the U.S. government fund directed research as private companies might have done, or in some cases were already doing. The most obvious case

20. Hounshell and Smith, Science and Corporate Strategy, show that R\&D played a strategic role very early at DuPont. The company needed substitute products and new uses for a large part of its huge munitions business after World War I. It tried to develop its own dye-making capabilities internally, but it was obliged to import at great expense a cadre of German and English dye researchers, with their families, to provide the necessary technological basis for the new business.

21. Lamoreaux, Sokoloff, and Suttiphisal, "Reorganization of Inventive Activity," summarizes what it refers to as two alternative modes of organizing technological activity: the large corporation with R\&D laboratory primarily in the Middle Atlantic and the smaller entrepreneurial enterprises in the eastern North Central region.

22. Koistinen, in Arsenal of World War II, shows that one military arm that continued to keep close contact with private companies was the Signal Corps. There was also continued contact between the Navy and RCA, which had been set up to continue U.S. Navy control of ship-to-shore radio. A third was Alcoa, which worked closely with the Navy on its duralumin program. A recent work affirming these ties is Epstein, Torpedo. In other words, despite the general discontinuation of direct control, the military, through its procurement functions, had more influence on the evolution of critical technologies between the wars than has generally been recognized.

23. Allison, New Eyes for the Navy. 
was the work on poison gas that was conducted at the Edgewood Arsenal in New Jersey, having been carried out in the private sector before World War I. ${ }^{24}$

In the interwar period, companies that performed research were generally considered to be contributing to the national interest. Some functioned as de facto sanctioned monopolies-controlling the way their industry developed by dominating the rate and direction of technological change. Some very large companies that crossed the line into predatory behavior, such as the electric companies, were charged with violating the antitrust laws in the 1920s and 1930s, but, in general, improving the country's technological standing was treated as an act of patriotism. ${ }^{25}$ In the 1920 s, research was mainly applied to productivity improvements, increasing corporate profits, and making industrial processes more efficient to the point that by 1930 industrial production had outstripped demand.

Public support for industrial science took a hit later, in the 1930s, for the "abuse of science" when more than a decade's emphasis on improving industrial productivity was popularly blamed for job destruction. ${ }^{26}$ It took a further hit when for three years, starting in 1938, the TNEC (Temporary National Economic Committee), in what was known as its monopoly hearings, exposed the extent to which large technology-based companies in many industries had colluded in the interwar period and used their patent monopolies to destroy smaller firms and competitors. As historian Richard John maintains, the TNEC, as an early instance of a committee convened by both Congress and the executive branch working together, prefigured the increasing postwar importance of regulatory activities and of economic policy setting. Moreover, the TNEC's connections through Thurman Arnold, with the aggressive program of antitrust enforcement carried out by the Antitrust Division in the late 1930s, made antitrust crusaders out of many of the young lawyers hired into the division who witnessed both the hearings and the court cases. ${ }^{27}$ Whatever the effect on legislated policy, both the hearings and the

24. Francis Frary, who directed Alcoa's Central Research program, worked on phosgene at the Oldbury Chemical Company before he was hired by Alcoa; he modeled the new Alcoa Research Center on the Edgewood Arsenal, where he led phosgene research during the war. Graham and Pruitt, $R \& D$ for Industry.

25. Reich, "Lighting the Path to Profit."

26. Pursell, Technology in America. At Alcoa, for instance, there was such sensitivity to public attitudes concerning the impact of productivity-focused technology that it was difficult for the Research Division to get the attention of senior executives to technological needs and opportunities, despite the well-founded rumors that Germany was investing heavily in aluminum capacity as part of its military build-up in Europe. Graham and Pruitt, $R \& D$ for Industry.

27. Waller, "Antitrust Legacy of Thurman Arnold." 
treatment of some offending executives made an indelible impression on the many business leaders who testified or who were, in some cases, convicted and fined for abusing the market power conferred on them by their patent holdings. The war brought a hiatus in antitrust activities, but in the war's aftermath, the need to pay attention to antitrust and related regulation became a more important aspect of big-company governance.

Given the role that industrial research was deemed to have played before and during the Depression, the scientists' rehabilitation in the public eye and rise to power in corporations and as government advisors was all the more impressive. In the late 1930s, with academic science suffering from Depression-era budget cuts, the scientific professions, led by men such as MIT's Karl Compton and AT\&T's Frank Jewett, lobbied the New Deal administration and the public for more government funding for science, in corporate research. Their arguments were that science did not have to be a job destroyer and that significant advances in physics and chemistry in particular could create whole new industries. ${ }^{28}$ This would have the attendant advantage of creating for U.S. science the stability and prestige that Germany offered its scientists through government funding and consultation. ${ }^{29}$ These efforts got a boost when U.S. leaders in government and industry, aware of the role that science was playing in Germany's military build-up during the 1930s, contrived to fund industrial research in a few key laboratories as part of the Lend-Lease Program. Prime beneficiaries of this funding were laboratories that were positioned to contribute to the most vital technologies under development for use in World War II, especially radar and radio communications, one of the few places where military and industry contacts had remained intact after World War I. ${ }^{30}$

If effective promotion by the scientific community helped to reposition science in the public mind, then the vaunted role of scientists in developing vital military weaponry on the fly during World War II completed the turnaround. Companies in many key industries contributed members of their laboratory staffs to the interdisciplinary efforts that produced radar, the Manhattan Project, the computer, guided missiles, and many other technology-based weapons and

28. Graham, "Industrial Research in the Age of Big Science”; Schweber, "Cornell and MIT,” 154-155.

29. For a general discussion of this development, see Kevles, Physicists. See also Lipartito, "Rethinking the Invention Factory."

30. Koistinen, Arsenal of World War II, on the continuity of procurement between the Signal Corps and its suppliers, says that this resulted in the problem that it was hard to separate procurement for R\&D and for product, and that this produced a constant condition of shortage through much of World War II. 
supply programs. ${ }^{31}$ Huge increases in federal funding for industrial research followed the war, and continued in ever-growing amounts for the duration of the Cold War, becoming what has been called the permanent wartime economy. ${ }^{32}$ The government increases in funding for research leveraged private funding as well, in amounts roughly equivalent to the government outlays. ${ }^{33}$

Industrial research centers in the postwar era, having become the first line of defense in a new kind of warfare, were caught in the crossfire between scientists, who wanted to return to normal, and the military, which considered that military funding should appropriately come with strings attached. Government funding for research conducted in corporate research centers started its steady uphill climb in the late 1940s. ${ }^{34}$ As Mowery and Rosenberg point out in their important study of funding for innovation in the United States, there has been a tendency to assume that increased funding led to better and more innovation. But the record suggests that more, even much more, was not necessarily better. The authors posit that the steadily rising amounts of government funding over such a long period increased the cost of research and narrowed the focus of innovation to a few industries and a few technologies chosen by the military. Meanwhile, the secrecy required, the divisions within the scientific community imposed by professional standards and government funding categories alike, along with differences in policy and practice with respect to publication and patenting, brought about profound changes in the culture of industrial research, particularly in companies that straddled the divide between military and civilian business.

31. Otherwise well-researched works on the technology of major wartime projects-radio, radar, and sonar-typically award credit for these remarkable developments entirely to the scientific teams that invented the technology. Little or nothing is said about the companies that contributed their R\&D staffs and their manufacturing expertise to the actual production of the vital components. I attribute this to the "top secret" classification of the work. According to Adams, the Harvard Radio Research Program, for instance-headed by Frederick Terman, who was hired by Vannevar Bush from Stanford-was top secret, and it is still difficult to find much about it in the public record. See Adams, "Stanford University and Frederick Terman's Blueprint."

32. Hounshell, "DuPont and the Management of Large-Scale Research and Development."

33. Mowery and Rosenberg, Technology and the Pursuit of Economic Growth. To my knowledge, no such data are available for expenditures on the part of the intelligence agencies.

34. Mowery and Rosenberg review what is known about the magnitude of this funding before, during, and after World War II. Ibid. While private funding for science performed by the private sector was reported to the National Science Foundation, a breakdown of the allocation of military spending for research was and remains classified. 
In the immediate aftermath of the war, corporate research and the companies that performed it benefited not only financially but also from major investments in human and social capital. For most of the leading defense contractors, the wartime projects produced a group of hands-on scientists and engineers uniquely qualified to lead innovative efforts. For those who spent their war working in the interdisciplinary weapons programs, the experience was as formative as the battlefield experience for leaders in other fields. Engineers and scientists who had experienced the thrill of urgent problem-solving and working with many different types of people carried a hands-on, project-oriented attitude with them back to their laboratories and experimental mills.

However, keeping a scientific staff intact after the war, in what is now commonly known as the Era of Big Science or Big Physics, was a challenge, as scientific salaries increased and opportunities proliferated. Executives made big concessions to attract and retain scientists. They moved corporate research to the top of the organizational hierarchy, giving it divisional status; they signed government research contracts to fund fundamental research, and allowed at least some researchers to publish their work; they allocated capital to house research in centralized campus-like facilities; and protected it from day-to-day interruption or product-oriented interference. How much of the public rationale for these practices was actually a way to justify walling off the research sites and programmatic decision making in the interests of maintaining military secrecy can only be surmised. But the conflicts that divided the scientific community as a whole between a military culture, which assumed secrecy, and a scientific culture, which embraced knowledge sharing and openness as primary values, were real. Speaking to the Westinghouse Awards Dinner in 1946, E.U. Condon, one of the nation's leading physicists, warned, "Right now we are confronted in America with a situation in which scientists are being held very strictly under military domination, to the severe detriment of our scientific development and the development of wholesome international relations." 35 Condon, who had been a participant in the Manhattan Project, and whose Physics textbook remained the standard for a generation, was respected in government, academic, and industrial research circles alike. He was, nevertheless, rewarded for his outspokenness by being denied a security clearance for access to classified information, ending his career in industrial research. ${ }^{36}$

35. E. U. Condon, speech to the Awards Dinner of the Fifth Annual Science Talent Institute, March 5, 1946. Condon enumerated the many contrasts between the way military and scientific operations were conducted.

36. Wang, "Science, Security, and the Cold War"; Kline and Lassman, "Competing Research Traditions in American Industry." 
In the 1950s and 1960s, the corporate research center became a new kind of place, a counterculture that, it was widely believed in management circles, required steady, patient, consistent support to be productive. At a time when many companies were growing rapidly, there was considerable power in the organizational stability the research organization enjoyed. With the rest of the company changing every couple of years, researchers had the comparative advantage of continuity. On the negative side, incoming researchers, newly minted PhDs with many opportunities, were a generation as difficult to manage as millennials are said to be today. ${ }^{37}$ When this new generation-especially the PhDs in Physics-took leadership in corporate research centers in the mid-1950s and early 1960s, especially in the large bureaucratic East Coast corporations, they prioritized theoretical disciplinary work and stigmatized as Brute Force research organized in the old style, team-oriented, way. Experimental mills were shut down and older style hands-on researchers were ejected or exiled to product divisions. ${ }^{38}$

New funding patterns also tended to reinforce divisions in the research community. The government designations of Basic and Applied Research, as much as they were intended to represent the type of research being performed, were important as a way of distinguishing between what could be shared as science and what needed to be kept secret as having immediate commercial value. Theoretical researchers funded by "basic" research money could be permitted to publish their papers as though they were in the university. For other forms of research, publication was restricted and disciplined habits of intellectual property protection were observed more meticulously than before. ${ }^{39}$ After World War II, which involved a temporary suspension of many critical patent rights having to do with military equipment and supplies, the fear of possible government ownership claims led companies to modify their stance toward their patent holdings and intellectual property protection in general.

37. Kevles, Physicists, a widely admired account of academic and government science, is virtually silent on corporate science, despite the large proportion of research performed by corporate laboratories. See also Buderi, Invention That Changed the World. It has the same bias toward science and away from application and execution.

38. Stuart and Kargon, in "Electronics and the Geography of Innovation," note this crippling problem for Eastern Laboratories and show that Bell Labs and RCA Labs hired Stanford's Terman as a consultant to establish more hands-on education of the sort he promoted at Stanford. East Coast universities, however, Princeton and Cornell in particular, rejected contact with business, and elevated theoretical research to the exclusion of more practical or more applied research. In the large eastern companies, their emphasis on theory prevailed.

39. Graham and Pruitt, R\&D for Industry. 
The TNEC had recommended that Congress pass legislation requiring companies to license all patents at a reasonable royalty. In the postwar backlash to the New Deal, Congress ignored this recommendation, along with much else that had been contained in the voluminous TNEC reports that were hardly allowed to see the light of day. Scholars have, therefore, concluded that, having instigated almost no change in formal policy, the TNEC was a "flash in the pan" with little practical effect on company behavior. But the prewar monopoly hearings had revealed for all to see just how patents, though individually legal time-limited monopolies, could be clustered for companies to use against competitors in a way that amounted to abusive behavior and restraint of trade. These revelations were not forgotten. Nor was it wise to ignore the possibility that the government might claim property rights in return for its funding. In theory, federal research funding, especially through the military, and related agencies such as Atomic Energy, gave government the right to require recipients of federal funding to license or even share their technologies free of charge. In view of this jeopardy, companies were more careful of the contracting relationships they undertook with government agencies, preferring to hide their activities by becoming second- or third-tier suppliers and leaving the prime contractors to cope with the more onerous restrictions and controls that military funding entailed. After declining to a plateau in the 1950s, the numbers climbed steadily in certain industries, but corporate patenting practice became increasingly more financialized. ${ }^{40}$ Just as independent inventors always had the option to sell their intellectual property or to exploit it themselves, corporations treated patents filed by their employees as different kinds of assets. While very broad and fundamental patents were used as a way of protecting an area a company wished to exploit commercially over the long term, in more cases patents were treated as financial assets and sources of possible licensing revenues. Previous practices of sharing among different companies' research laboratories came to an end. Some firms elected to protect their intellectual property as trade secrets, a more primitive approach that was made feasible by classification and the virtual isolation of the remotely located and secured central laboratories. Patents could wait to be filed when companies were ready to take a product to market. As patents turned into bargaining chips to be exchanged with would-be foreign competitors, numbers of patents mattered more than the claims or the content, especially with Japanese companies, which in the 1960s started putting an emphasis on turning out patents for patents' sake. ${ }^{41}$

40. “U.S. Patent Activity Calendar Years 1790 to Present,” https://www.uspto. gov/web/offices/ac/ido/oeip/taf/h_counts.htm.

41. Nishimura, "Measuring Innovation." 
Antitrust prosecutions had been suspended during World War II, but in the postwar period, young lawyers, the "trustbusters" who had worked in Thurman Arnold's Antitrust Division of the Justice Department, picked up where they had left off. ${ }^{42}$ Enforcement tactics now changed, however, from the aggressive "shock and awe" approach of the late 1930s to a somewhat more modulated practice of allowing offenders to negotiate behind the scenes and to plead no contest. An antitrust division that had previously employed only a handful of lawyers increased in size to five hundred lawyers, enough to both prosecute and monitor corporate behavior on an ongoing basis. As the prolific jurist Robert Posner explains in his writings on the beginnings of "law and economics," it was in the field of antitrust that pathbreaking efforts, if "unsophisticated," were made to decide cases based on economic valuation rather than on morality. ${ }^{43}$ Following the landmark decision by Judge Learned Hand that found Alcoa to be a monopolist not because it was proven to have abused its market power (a hard case to prove against expertly represented companies) but because it controlled a very large share of its market, legal scholars and jurists narrowed the acceptable arguments for concentration to measurable efficiencies, resulting in lower prices for the consumer. All other arguments intended to justify behavior that might constrain trade, including superior performance, social benefit, or political benefit, were no longer admissible. ${ }^{44}$

Historian Tony Freyer shows that in the 1950s and 1960s, the Justice Department was instructing the bar, especially that part of the bar that advised large companies on antitrust matters, to counsel corporate clients that the way to avoid prosecution by the Justice Department and to maintain the growth they desired was to diversify into unrelated markets. As lawyers achieved higher positions inside corporations, often offering daily advice to CEOs and sometimes becoming senior executives themselves, ${ }^{45}$ and as more economists joined the boards of large

42. Waller, "Antitrust Legacy of Thurman Arnold"; Hart, "Antitrust and Technological Innovation." See, for example, the case of Timken roller bearings, which was the object of antitrust action in the 1930s, and whose case was picked up again after World War II. Pruitt, Timken, 159-160.

43. The language of the 1948 federal court decision against the Timken Company reveals the moral bias implicit in the language of the law. Timken was forced to divest its stock in British Timken and Timken France because it was not a full owner of the companies and operated under licensing agreements that were deemed to restrain trade by explicitly dividing the market between these companies and Timken USA, keeping costs up for roller bearings in the domestic market. The court statement read, "Such business arrangements should not be destroyed unless necessary to do away with the prohibited evil" (my emphasis). See Pruitt, Timken.

44. Posner, "Values and Consequences."

45. Freyer, Regulating Big Business, 301-303. 
companies, the efficiency-inspired tenets of the "law and economics" philosophy gained greater influence inside the corporation as well as in court proceedings and law school classrooms.

At the same time, the strictures on acquiring closely related companies or setting up subsidiaries in the same markets became muddy at the water's edge, as did the prohibition against misusing patents. These differences encouraged companies that wanted to maximize their licensing revenue, or cluster their patents to restrain the activities of competitors, to set up subsidiaries and to license their intellectual property overseas. ${ }^{46}$ The effects of antitrust enforcement are typically seen in the opportunities opened for new entrants into markets that had previously been dominated by monopolists. We also know something about the effects of antitrust enforcement in companies that have been dismembered on antitrust grounds, such as AT\&T. We know less about the effects of less visible penalties, or of the monitoring regime that could carry on for decades. Though the law of unintended consequences is often cited, the misleading assumption still seems to prevail that what policy intends is what policy achieves.

Ironically, the more power and privilege research enjoyed within the formal corporate hierarchy, the less effective centralized corporate research centers would be at guiding and transferring technology. Staff members who had been exiled to the ever-spreading divisions were disinclined to accept orders from the center, or to work on projects they believed had been selected to benefit corporate research rather than product divisions, or the company as a whole. The more ambitious or unfamiliar the science, the more proprietary the technology, the less welcome it was to those in far-flung divisions that had to develop it into products, and less often, processes. The difficulties increased when at the executive level the professional managersthe alumni of leading companies like Ford, IBM, and ITT—scattered throughout U.S. industry, spreading their professional orthodoxies of "management by the numbers," speed and efficiency, market share, and net present value. ${ }^{47}$ With such tools in their kit, professional business managers believed that general managers could manage any business, regardless of experience. For more than a decade the conglomerate, a set of diversified businesses, became a common form of enterprise intended to spread financial risk and off-set cyclical downturn. In the decades following World War II, corporate research programs enjoyed impressive increases in the size of their budgets, but

46. Freyer, Antitrust and Global Capitalism. Here, the concern to regulate big business clashed with the concern for foreign trade. Moreover, the U.S. Justice Department's authority and jurisdiction were too limited to enforce policies consistently in offshore businesses.

47. Graham, "Financing Fiber." 
by the 1960s, the first era of "Moonshots," they were obliged to take on larger and larger projects to keep the attention of executives who often lacked technological expertise and considered market probes and small experiments unworthy of their notice.

How corporate research adapted from meeting vital wartime needs, to managing hugely increased levels of funding, and how it evolved to accommodate the changing interests of professions in the company—scientific, managerial, and legal—can be seen in the stories of RCA and Xerox as they made strategic choices around their intellectual property and contended with the abiding presence of antitrust scrutiny and other forms of regulation.

In 1942 RCA consolidated and centralized its recently assembled advanced research staffs in a spacious new laboratory near Princeton University. Less than a decade later, CEO David Sarnoff renamed the research center the David Sarnoff Laboratories, and so it remained for more than fifty years, long after RCA itself had disappeared into General Electric.

Almost three decades later, in 1970, with much less fanfare, the Xerox Corporation set up a very similar-sized advanced research laboratory in Palo Alto, California, close to Stanford University, and far from Xerox's main corporate research laboratory in Webster, New York. PARC was the last advanced research center to be set up by a large American company for a generation, the form having for the most part gone out of fashion. Though neither Sarnoff nor PARC originated with that explicit justification in mind, both Laboratories would be called on to serve an entrepreneurial function for their companies, not just to provide research or inventions leading to major new products but also to lead, and in some cases even execute, the commercialization process. One vital assumption motivating both establishments was that a corporate research laboratory could be, or needed to act as, the surrogate for an entrepreneurial CEO, organizing and motivating the many aspects of product, device, component, and systems innovation that had to be accomplished if corporate research were to fulfill its strategic mandate.

\section{RCA Laboratories Become Corporate}

When David Sarnoff ${ }^{48}$ opened the RCA Laboratories near Princeton, New Jersey, it was the fulfillment of his dream to gain RCA's

48. This section on RCA and the David Sarnoff Laboratories draws on Graham, RCA and the VideoDisc; Bilby, The General; Radio Corporation of America, 1942-1967: Twenty-Five Years at RCA Laboratories. 
independence from its parent companies, General Electric and Westinghouse. Sarnoff was the radio and broadcasting manager, and a self-taught engineer (at a time when many engineers were self-taught), who had been tasked with operating the ship-to-shore radio service of the old American Marconi. When American Marconi became the Radio Corporation of America, Sarnoff was also tasked with holding and administering a valuable pool of radio-related patents from the parent companies in the Radio Trust, including General Electric, Westinghouse, AT\&T, and United Fruit. Lacking the manufacturing and the research to back up the new businesses, Sarnoff capitalized on the one reliable source of revenue he could generate that was completely under his own control-the licensing of radio-related patents, which provided regular ideas from licensees, and for which RCA employed the controversial practice of "package licensing" to make it easier to deal with the annoying radio amateurs and fly-by-night startups he had to collect royalties from. Package licensing required those wanting to make use of any of the patents in the pool to pay for the whole package at a royalty much higher than they would have paid if they had been able to pick and choose. RCA also refused to license would-be competitors, and sued them if they tried to buy components from international producers. ${ }^{49}$ This licensing cost borne by all radio and electronics companies considerably reduced technological competition in the radio industry, but it was tolerated before World War II because it gave the U.S. Navy control over long-distance radio technology and reduced the problem that divided technological control that could put a stop to progress in radio altogether.

Sarnoff struggled with the bureaucracies of his parent company/ suppliers for nearly a decade before he finally got what he wanted: an integrated company of his own. Independence came in 1930 when the first antitrust steps were taken to break up the Radio Trust, but it was not until 1938 that Sarnoff finally accomplished the full-scale corporate integration he had been seeking. He took over the New Jersey laboratories of GE and Westinghouse that served the radio manufacturing plants and blended their staffs with the staff of his recently acquired Victor Talking Machine Company. ${ }^{50}$ Significantly, a large part of this act of enclosure was financed by the U.S. federal government through the Lend-Lease Program, and much of it was devoted to improving vacuum tubes. Because of its dominant position

49. Lécuyer, Making Silicon Valley, 25, shows how RCA's monopolistic practices forced western electronics companies to improve by stretching to bypass RCA's patent holdings. This was a rewarding but risky approach, as some such attempts, such as Sylvania's, ended in lawsuits and failure.

50. Aitken, Continuous Wave, gives an exhaustive account of Sarnoff's machinations to achieve independence from Westinghouse and General Electric. 
in vacuum tubes, RCA was the fourth-largest recipient of federal research funding during World War II. ${ }^{51}$ But you might say, Sarnoff had traded one form of dependence for another.

Sarnoff used the federal funding and procurement contracts to build a consolidated central laboratory, in the New Jersey countryside, devoted to advanced research in electronics. The topsecret research performed there required the facility to be in a remote location that could be effectively secured. It was located near Princeton, equidistant from Manhattan, New York, and from Camden and Harrison, New Jersey. For the first seven years, the center was devoted to war work-advanced electronics research backing up the multidisciplinary projects involving all the radio companies centered around MIT_on radiation and missiles. After the war, RCA was ideally positioned to leverage the wartime expertise to commercialize black-andwhite television. It benefited from pent-up demand from returning servicemen trained in electronics, and from defense plants purchased from the government for 10 cents on the dollar. In similar circumstances, most firms would have milked black-and-white television for as long as they possibly could, but Sarnoff pushed immediately for a full-scale R\&D effort on color television, attempting to launch well before it was ready. He called it self-obsolescence, but the reason was clear: he needed a program challenging enough to keep his research staff together.

Thus, what seems in retrospect like a vainglorious gesture in 1951—naming the laboratory after himself—was not simply a gesture. It was Sarnoff's way of publicly committing himself and the entire company to a strategy of following electronics "wherever it would lead." Sarnoff not only retained his research staff but also forced the various divisions in the RCA system to align behind his plan for products on his timetable. As long as he was able to provide this entrepreneurial leadership, RCA could be highly innovative and highly successful-the undisputed, though widely resented, leader of the U.S. consumer electronics industry.

\section{RCA (Independent) and Antitrust}

Even with the success of the radio business and a triumphant blackand-white television business behind him, Sarnoff was preparing

51. Sarnoff Laboratories was the fourth-highest recipient of military research funding during World War II. As well, RCA was one of the top five suppliers of communications equipment to the Signal Corps. Koistinen, Arsenal of World War II, 35. 
for the time when he would need an entrepreneurial successor. He chose not his son, Robert, who was being groomed to take over the company, but his namesake, the corporate laboratories. He made the Princeton establishment a division in its own right, reporting to him at the top of the organization. The steady sums of money that came to RCA as licensing revenue funded the research effort. RCA also accepted increasing amounts of federal funding for research, not only to support RCA's diversification into military components and systems but also to afford and attract the $\mathrm{PhD}$ physicists who were in short supply and came at such a salary premium. Each year Sarnoff allocated the money it requested without batting an eye. Thus what emerged became RCA's growing counterculture, similar to the situation at other large corporate laboratories, especially Eastern Laboratories. ${ }^{52}$ A large gap in values opened between the self-identified problem-solvers organized in teams of an earlier time, and the lone theoreticians of the middle century. Naturally, when the time came to transfer work that had been performed at the Princeton laboratories to some of the divisional laboratories, the technical staffs there were eager to find fault with what they were asked to do. They called it "turning pearls into necklaces." Egregious cases of this sort occurred with RCA's effort to produce transistors at its Lancaster Tube Plant, a former GE tube plant built for wartime production, or again when RCA tried to manufacture its own glass for its glass picture tubes. ${ }^{53}$

By the mid-1950s, Sarnoff's entrepreneurial energy had run out of steam. He was too distracted to deal with RCA's internal competition himself. He faced not only the problems of carrying singlehandedly the color television business that competing companies had refused to join-mistimed because of the need to hold together his research team-but also a new problem: the unwelcome attention of the Justice Department backed by the ever-noisier complaints of the now enlarged radio and electronics companies that objected to RCA's package licensing practices. RCA was caught in the antitrust spotlight that had shone on the electric companies before the war. The one-sizefits-all licensing approach called "package licensing” that RCA had developed to milk its irritating radio competitors was a glaring anticompetitive practice. Small companies complained to the Justice Department that it handicapped them when competing in radio and television manufacturing and kept them out of areas where they had been able to do research during the war. When companies such as

52. Graham, "Industrial Research in the Age of Big Science."

53. Seen from the Corning Glassworks perspective, this story is recounted in Graham and Shuldiner, Corning and the Craft of Innovation. 
Philco, ignored before the war, clamored for relief in the mid-1950s, the Justice Department was ready to give it to them. ${ }^{54}$

A crisis erupted in the life of Sarnoff Laboratories when RCA confronted the antitrust charges by the Justice Department. In anticipation of a negative outcome, Sarnoff warned then-head of Research, Dr. Elmer Engstrom, that the Laboratories must prepare for the first time to live within a budget. As the company pled nolo contendere and agreed to cease its package licensing practice to domestic licensees, Sarnoff famously remarked that he would do a lot for RCA, but he would not go to jail for it. The Laboratories prepared its budget request as instructed, but the budget was never implemented. Instead, RCA quietly turned to package licensing the Japanese electronic companies that were eager to gain access to advanced electronics after the war. In 1960 the Japanese government awarded David Sarnoff its highest honor for a foreigner: the Order of the Rising Sun Second Class, calling him the Father of the Japanese Electronics Industry. One side effect was that RCA never launched an international business in consumer electronics because it wanted to avoid competing with its all-important licensees.

A significant change from RCA's all-electronics mission, or at least something that diluted the technology-intensive character of the company-and with it the support for its central researchwas a change in RCA's strategy. While RCA was spending heavily to support color television on its own, Sarnoff was persuaded by the financial experts on his board, and likely by legal advisors as well, to fund the next major push into computers by diversifying the company. The idea was that a conglomerate put together much like a stock portfolio would provide steady returns and reliable cash flows to invest in the computer business, which would offset the volatility inherent in a strategy based mainly on supporting reinvigoration of the consumer electronics business through new products and expanding the computer business into new markets. As we can surmise from more recent work on the nature of postwar antitrust policy and enforcement, legal advisors would have supported the conglomerate strategy as a path to growth that would steer RCA clear of further antitrust trouble. RCA's acquisitions in the mid-1960s went from reasonably related ones, like Random House, which made sense for a company that was already in the information business with NBC, to a slew of quite unrelated companies that could only have made sense to the investment companies that collected the fees associated with the acquisitions, some of which were represented on RCA's board.

RCA's leaders, meanwhile, coming from IBM and from Ford, were chosen for their ability to guide RCA in its quest to grow in the computer

54. Bilby, The General. 
business and to compete with IBM. These were not innovators but competitors, monitoring market share numbers on a weekly basis and relying on RCA's established position in the consumer electronics market and its strong network of dealers to maintain its leadership there. Their main interest in the consumer electronics business was to use it as a platform to support the computer initiative, an approach that precluded modernization of its manufacturing capabilities. Further in line with general trends in the industry, RCA's last act of conglomeration was to acquire a financial company.

Meanwhile, RCA's Japanese licensing activities were expanding. All the major Japanese companies took the licenses, and RCA's licensing revenue soared. At a time when both the color television business and the expanding computer business were draining the company's working capital, the overseas licensing revenues made the difference between profit and loss. Sarnoff Laboratories would continue to benefit from this Japanese licensing arrangement into the 1980s. Having a stable source of funding, renewable every three years, and identifiably related to its own patent output was exactly what it needed to maintain the conditions deemed necessary for high-level research. The laboratory staff continued to perform a valuable and visible national role - publishing papers in advanced electronics, patenting inventions, and training scientists.

It is not clear, however, if anyone acknowledged the downside to the new enhanced licensing arrangement for the company. When choices had to be made in new product programs such as the video player, which was conceived of in the early 1960s as part of a Selectavision family of products, how could the Laboratories be blamed for, or even prevented from, favoring solutions that involved the maximum amount of proprietary technology, regardless of how suitable it was for a new consumer product or how acceptable it was to the RCA divisions that had the task of manufacturing it? It was, perhaps, also inevitable that the RCA product divisions, which received little technical support from the RCA Laboratories, tended to look to licensees for help with development on even the most sensitive product programs, nor was it surprising that the Japanese licensees were happy to offer their help with development on discrete bits of the project. It was RCA's marketing expertise, not its technology, which ultimately made the VHS video recorder from JVC and Matsushita the enormous success that it was in the U.S. market, foreclosing the path for VideoDisc to break through. ${ }^{55}$ Likewise, it was RCA's Japanese licensees that were

55. Ranganath and Ketteringham, "JVC and the VCR," allude to these relationships between Japanese firms and foreign firms in their discussion of the successful Japanese takeover of consumer electronics. 
the first to commercialize many promising technologies that were invented in the Princeton laboratories. When General Electric acquired RCA in 1985-1986, it transferred the Sarnoff Laboratories, renamed Sarnoff Corporation, to the Stanford Research Institute (SRI), which was in a position to maintain those programs that were important to the government. GE kept the RCA brand for only a year and then sold it to Thomson, violated some of the other commitments it had made to get the deal, and forgot the rest.

\section{Xerox and PARC}

During the enclosed period of corporate R\&D, Xerox's story parallels RCA's. ${ }^{56}$ Joseph Chamberlain Wilson, the entrepreneurial CEO of a small printing company in a declining business called Haloid, recognized in inventor Chester Carlson's very-far-from-fully-developed prototype for a plain paper copier a life raft for his declining business. ${ }^{57}$ Though Carlson had developed a working prototype at Battelle Laboratories, the copier prototype had already been rejected for adoption by most of the obvious suspects (IBM, AT\&T, Kodak). Joe Wilson decided to take it on, and stuck with it, and with Carlson, until it became the renowned Xerox 914 copier. This machine-leased and maintained and paid for on the basis of clicks (cost per page)—became so successful that it put Xerox among the "Nifty Fifty" stock market leaders and made the entire staff of Haloid-turned-Xerox and their investors very rich. Introduced in 1959, the 914 was not replaced in the market until the mid-1970s. This was not for lack of trying by engineers at Xerox's main Webster Laboratories. Several attempts to replace the 914 with newer models, and to develop other lines of business organically failed, including one very large and prolonged electronic copier project called Moses, which was supposed to take Xerox to the Promised Land.

Unlike David Sarnoff, Joe Wilson was less obsessed with the imperative of self-obsolescence than with the imperative of growth that gripped professional managers in the 1970s, as the conglomerate craze was collapsing. Was it possible to grow quickly without risking prosecution and without taking on businesses that were unrelated to the existing

56. This account of the founding of PARC is based on Ellis, Joe Wilson; on Owen, Copies in Seconds; on Hiltzik, Dealers of Lightning; and on the author's interviews with George Pake and many early PARC employees, conducted in 1991 while on sabbatical at the Institute for Research on Learning at Stanford University and at Xerox PARC. The further discussion of later Xerox policy toward spin-offs draws on Chesbrough, "Graceful Exits."

57. Dessauer, My Years with Xerox. 
business? With the cash flow from the 914, he acquired a slew of related businesses. He and his successor, Peter McColough, also hired a group of more "professional managers," again from Ford Motor Company, whose main skill, despite the huge cash flows thrown off by the 914, was cost-cutting and not investing in current products.

It was Peter McColough, however, who judged that Xerox needed to enter the computer business at any price, and acquired a computer company named Scientific Data Systems (SDS). ${ }^{58}$ To provide research support in computer science that the Webster Laboratories was not able to muster, McColough hired Jack Goldman, also from Ford, appointing him head of the research division and chief technologist. At the time, Xerox had settled on a distributed approach to research, with different laboratories concentrating on different areas of research. ${ }^{59}$ At the same time, the company maintained its oddly antiquated functional organization, with research reporting in at the top of the organization completely separate from manufacturing, which also housed development. Reporting directly to the CEO, Goldman was empowered to set up a first-rate new computer research laboratory. As computer science was still in its nascent phase, especially where independent software was concerned, Goldman aimed to bring together an interdisciplinary team of researchers drawing on several different disciplines. He hired Stanford graduate and former chancellor of Washington University at St. Louis, Dr. George Pake, a solid-state physicist who went about setting up an interdisciplinary laboratory of some two hundred research scientists and engineers, including what were later said to be fifty-nine of the top computer scientists anywhere, even though computer science was still in its infancy. Unlike the RCA Laboratories, aka the Sarnoff Laboratories, the new Xerox research center, which Goldman envisioned as on a par with Bell Labs or IBM Research, was located in Palo Alto, California, close to Pake's alma mater. Stanford already worked closely with a collection of thriving electronics companies in the vicinity, especially

58. As Shane Greenstein points out, the frontier computer business by this time was an important crossover business for any company that wanted to remain a high technology firm, and Xerox could hardly afford not to have access to computer technology under government auspices when its government business was as important as it was and increasingly in line with its enterprise business.

59. Myers, "Research and Change Management in Xerox." Myers, head of research for Xerox in the 1990s, explained Xerox's distributed organization of research as a reaction to the failure of companies like RCA to make major technological transitions, such as the one from the vacuum tube to the transistor. He also noted that the separation between research, which reported directly to the CEO, and development, which reported to manufacturing at Xerox, exacerbated the communications problem between research and the product divisions, even after Xerox adopted a divisional structure. 
Varian, maker of high-performance vacuum tubes, and Hewlett Packard (HP), maker of precision measurements and minicomputers, among many other technologically sophisticated products. The culture of what was coming to be called Silicon Valley differed markedly from that of the hierarchical eastern companies. Even in its eastern locations, Hewlett Packard, for example, organized itself in small units and maintained a much more egalitarian culture. ${ }^{60}$

Goldman lured the high-caliber computer scientists he wanted to hire by promising them unbelievably favorable research conditionsno copier research, no product or profit required-and ten years of very generous funding. (These promises were kept through thick and thin and were most likely strengthened by requirements associated with NSF funding for research and designation of PARC as one of the nodes on the ARPANET, which could not be used for commercial purposes at the time.) PARC's goal, set by Pake, was to create the "office of the future," in which McColough presumed SDS computers would occupy a central position. The reason generally given for locating PARC so far away from Xerox headquarters was not only that SDS was on the West Coast (though several hours distance by plane from Palo Alto) but also that the conventional wisdom among research directors had shifted as a consequence of the difficulties companies like RCA had with trying to produce transistors in conventional vacuum tube plants. The new conventional wisdom was that leading-edge laboratories should not only be independent but that they should be remote. Another big difference from earlier advanced research laboratories was that PARC wanted its researchers to get their hands dirty. As George Pake was fond of pointing out, good physicists were expected to design and build their own research experiments: the notion of scientists embodying their ideas in working prototypes was an essential component of the new laboratory.

The shifting political economy of the time points to some other interesting reasons why an advanced computer research laboratory located in Palo Alto might make sense. During the late 1960s, opposition to the Vietnam War and the draft, especially among university students and some faculty, raised concerns about the dominance of military funding for university research in the sciences. One of the key places where this concern was raised on the West Coast was Stanford, where the pressure became intense enough, and the difficulty of recruiting scientists to work on military research and research linked to other branches of the government inside universities

60. See Adams, "Stanford University and Frederick Terman’s Blueprint.” See also Lécuyer, Making Silicon Valley. 
became serious enough, that the Stanford Research Institute, home to such legendary computer pioneers as Douglas Engelbart, was cut free from Stanford in 1970. George Pake, hired to direct the PARC research effort in that same year, had only recently stepped down as chancellor of the University of Washington, St. Louis. This Midwestern university had been one of the chief recipients of military research funding since World War II, and was not coincidentally home of the third famous Compton brother physicist, Wilson. Pake had tired of coping with the problems of recruiting scientists into university research when student outrage concerning the Vietnam War was so high. The government, too, was looking for different ways to fund research less obviously directed or connected to academia. Funding research at a leading private computer research laboratory close to Stanford was one way of furthering the government's long-term research agenda without having to reveal what was being worked on with the same transparency that would be required of most academic research programs. It can be no coincidence that shortly after its founding, PARC became the largest volume user of the ARPANET by far of all the nodes on the network. The way it was set up, covering all aspects and components of computer research, from electronic devices to software, though not closed to the outside world to nearly the same extent as earlier industrial laboratories, guaranteed it intellectual and practical self-sufficiency. In fact, it was an ideal one-stop shop for the rapid development of novel computer tools and software.

Contrary to the original plan, PARC computer scientists refused to cooperate with SDS, the new computer subsidiary to which their research could be expected to apply. When Xerox refused the PARC staff's requisition for a DEC minicomputer, on the grounds that they were expected to use an SDS computer, the PARC research staff built their own superior version of the DEC PDP 11, the reigning academic computer of the time. With the mordant humor that characterized PARC's attitude to most other parts of Xerox, they named their computer MAXC, after the SDS CEO. That they achieved this feat in just a few months permanently soured the PARC-SDS relationship. In other ways, however, the new lab was incredibly prolific.

Although given a ten-year mandate and a promise not to have to support the copier business in any way, PARC started producing prototypes of new machines and software that related to the idea of a futuristic office almost immediately. In the space of three years, they invented revolutionary parts of a system that, when combined, formed the first working model of a personal computer powerful enough to satisfy engineers who had previously been doing their work on minicomputers and time-shared mainframes. PARC eventually produced over a thousand of the small powerful computers they called Altos, 
selling them to engineers throughout Xerox and to leading university departments of computer science. The computers were small enough to fit under a desk, had a graphical user interface with windows and a mouse, and were networked to each other by means of another PARC invention, the Ethernet connection, in a new distributed configuration called the client-server architecture. Concurrently, led by one of the few engineers from Webster Laboratories who transferred to PARC, the young research center staff developed a working laser printer (which eventually repaid Xerox many times over for its PARC investment). ${ }^{61}$

Unfortunately, these achievements occurred just as Xerox's patent monopoly for the copier was brought to a premature end by order of the FTC in 1973. Like RCA in the 1950s, Xerox executives were plagued by several serious distractions, including unforeseen competition from Japanese producers, and the unwelcome attention of antitrust enforcers goaded by IBM and Kodak, which wanted to enter the copier business. ${ }^{62}$ Having enjoyed its monopoly for such a long time, Xerox was caught completely off-guard when Japanese companies introduced smaller, cheaper copiers and IBM and Kodak introduced versions of plain paper copiers that were not dependent on Xerox intellectual property. Xerox had entered into a strategic alliance with the Japanese company Fuji Photo in 1964, and it had long been aware of the mutual opportunities in sharing its technology with the Japanese, including royalties, profits, and industrial intelligence. It had mistakenly viewed the arrangement not only as a steady return to its technology but also as a kind of insurance policy. ${ }^{63}$ Like RCA, it had neglected to modernize its domestic manufacturing capabilities, intending to rely on electronic breakthroughs to make mechanical process improvements obsolete.

Faced with the unaccustomed competition at home and abroad, the last thing Xerox management wanted to attempt was to enter the completely unfamiliar business that exploiting PARC's new inventions would have required. Even the laser printer, which was directly applicable to a printer business Xerox ran out of Texas, languished for five years before Xerox was spurred into action by IBM's introduction of its own version of a laser printer. Meanwhile, Xerox was looking to its Webster Laboratories to produce the thousands of minor to trivial patents it needed to cross-license with Canon and others. This financial

61. See Gladwell, "Creation Myth,” for an account of Gary Starkweather's transfer from Webster to PARC and his successful effort to develop the laser printer.

62. Kearns and Nadler, Prophets in the Dark; Hiltzik, Dealers of Lightning; Smith and Alexander, Fumbling the Future; Chesbrough, "Graceful Exits."

63. Jacobson and Hillkirk, Xerox, 210-211. 
exploitation of intellectual property was a complete turn-off for scientists at PARC, many of whom were averse to patenting as a general rule, as software was not traditionally patented, but especially so if the patents were technically meaningless.

Unlike at RCA, where the research staff could keep doing what it most wanted to do (publishing papers and applying for patents) because of the stream of licensing revenues directly attributed to its efforts, the failure of Xerox to pay serious attention to commercializing technologies from its West Coast laboratory deprived its next-generation scientists of what they wanted most: to see their brilliant ideas turned into systems and products. Whether the lack of attention from the East Coast was simple neglect or whether funding and direction were coming from government customers such as the intelligence agencies, which had a clear interest in the speech recognition and large database technologies that were among PARC's areas of research, is largely a matter for speculation. From 1975 on, when Xerox refused to extend or further commercialize the Alto program, PARC experienced a steady exodus of its leading researchers. ${ }^{64}$ With them went their ideas, their expertise, and their entrepreneurial drive. In the early 1980s, the names of PARC alumni appeared on the roster of the growing PC-related businesses Microsoft and Apple, along with numerous start-ups, many of which became some of the largest and most enduring businesses in Silicon Valley, such as Adobe, Sun Microsystems, and 3 Com. The losses to Apple and Microsoft were particularly aggravating, as these two companies were making businesses out of the concepts they had acquired at PARC. Later they would sue each other for violating intellectual property rights that both admitted were derivative from PARC "prior art." When given the chance to invest in some of these businesses, or support scientists proactively to go out and start new enterprises with Xerox's backing, Peter McColough refused, fearing that it would drive researchers away. They left anyway. Even those who stayed at PARC were far more likely to share what they were working on with outsiders, a practice made easier by the developing ARPANET. According to Henry Chesbrough, in a study of how Xerox went about spinning off the many ideas

64. Some writers, including Henry Chesbrough in his otherwise excellent piece, "Graceful Exits," assume that the Xerox Star, a networked small computer offered by Xerox to the institutional market as a next-generation replacement for the IBM Selectric that dominated typing pools, was derived directly from the Alto. To the PARC researchers who invented and used it, it emphatically was not. While the Star had a similar configuration to the Alto, it was so underpowered, and at the same time required so much special training, that it was unsuited for the expert engineer or scientific user who required both large computing power and ease of use. Author interview in 1993 with Stuart Card, PARC research staff. 
that came out of its laboratories, mainly from PARC, but occasionally from Webster Laboratories and Canada, the company did not adapt well to, or even recognize the significance of, the changes that occurred in the late 1970s and 1980s. These included the rise of private venture capital, the open source movement (embraced by PARC scientists, but never grasped by the company's leadership), and the opportunities presented by the Internet. Although the company tried three different formulae for spin-offs-start-ups that wanted to exit the company-they never found the combination of up-front investment, incentives, and risk reduction that companies such as Intel employed more successfully in their corporate venturing. As with RCA, a central problem was the hang-up with proprietary technology that plagued so many companies with central laboratories as they tried to make the transition to the new era. ${ }^{65}$

\section{Conclusion}

To conclude, I had an intimate connection with both of these laboratories. I began my career doing research at RCA and I spent four mid-career years as a senior manager at Xerox PARC. In between those two engagements, I worked with and studied several other corporate laboratories, all the while trying to answer the research question that animated the RCA project. How did major corporations, which were generally regarded as less suited to innovation than smaller, nimbler companies, organize themselves for innovation? Would they, in fact, in their self-sufficient form, continue to replace the entrepreneur of the previous era? What I saw at RCA in the 1970s made even the idea of "intrapreneurship," then touted in the management literature, seem implausible. Current RCA managers scoffed at David Sarnoff for his flexibility (keeping his organization chart on a magnet board) and his color television development teams as practitioners of Edisonian "cut and try." In fact, during that time, in academic circles, entrepreneurial leadership was viewed as the antithesis of professional management, much like family business, and beneath serious study. When I joined Xerox PARC in the 1990s, the gulf between the East Coast big company mentality and West Coast culture was so large that I could not even imagine an interdisciplinary hands-on WilsonCarlson team supported by optical researchers and materials wizards producing the 914 copier in the 1950s. The generation of scientists I worked with might have been less attached to theoretical research

65. Chesbrough, "Graceful Exits.” 
and more open to getting their hands dirty, or at least doing fieldwork, but they were professionals first, wedded to their particular academic niches and alienated by the large corporation that paid their salaries.

Ironically, just as academics were learning how the large corporation had been organizing for, and struggling to execute, innovation in the closed system, the innovation system in the United States was opening again. Some of the openers were thwarted corporate entrepreneurs impatient with increasingly bureaucratic decision making. Another opener involved changes in the Employee Retirement Income Security Act, which freed institutional investors, such as pension funds, to make riskier investments, making more capital available for start-ups. And an important enabler was the technology itself, which brought computer technology down to human scale and made independent software a consumer item. But a big factor that was not so visible at the time was the readiness of knowledgeable receptive buyers and investors to innovate on the edge. For both RCA and Xerox East, these buyers were the Japanese companies, interested in acquiring technology and ready to pay for it, because they knew how and were equipped to adapt it for consumers. For Xerox PARC, on the other hand, the receptive buyers on the edge were the government agencies that valued superlative performance, and the corporate renegades and gifted amateurs in Silicon Valley who envisioned what next generation computers would be able to do if made more user-friendly. It was the unintended consequence of the antitrust pressure and the financialization of the patenting practices that made these various outsiders by far the most receptive to the proprietary knowledge both laboratories had to offer.

I now see that the way corporate research changed as an institution, gradually deteriorating in its enclosed form, had as much to do with changes in the way the corporation was affected by its institutional context as it did with the redefinition of professional management along military lines and its misguided restructuring of the organization. These included the shift in how government funding was administered and procurement was managed, the broadening and deepening of military secrecy measures into national security measures, the changes in antitrust enforcement, and the increasing financialization of intellectual property, with resulting changes in patenting practice. Rereading my work, I am struck by the way we framed things at the time-how we measured scientific achievement in industry (Nobel Prize counts and percentage of PhDs in corporate laboratories rather than technologies put to constructive and profitable use), our acceptance of flimsy explanations for extended classification in areas that we could have challenged under the Freedom of Information Act to dig into more deeply. We did not question the scorn heaped on entrepreneurial leadership as lack of professionalism. Nor did we realize 
what a fight it was for entrepreneurial leaders such as David Sarnoff to inspire his scientists and engineers amidst the postwar admiration for command-and-control management and the scientific emphasis on theoretical research. As attorney-client advice is privileged and is most often kept secret, it did not occur to me that the turn to the conglomerate form, which seemed so counter-productive from an innovation perspective, was not just the conflict of interest of investment bankers sitting on corporate boards but also was being promoted by the Department of Justice as an industrial policy. But I am thinking like a business historian. If I also think like a historian of technology, then I might credit the reopening of the innovation process to the advanced laboratory that Xerox located in Silicon Valley, and to the enabling technologies that Xerox, among others, helped to invent, develop, and combine: the copier, the laser printer followed by the computer-controlled printer, the Ethernet protocol, the accessible interface, the networked personal computer, and, of course, the Internet. Once the infrastructure had incorporated these technologies, closed innovation would be hard to accomplish even if enclosed in a laboratory.

Both RCA's Sarnoff Laboratories and Xerox PARC were one of a kind, of course. It could be that the unintended consequences of changing policies and institutions covered here took completely different forms in other companies. But evidence from studies that were not available two decades ago, although fragmentary, suggests that corporate behavior took odd turns in many of them. I hope further reinterpretation will continue to uncover the often-circuitous routes by which political economy affects the ability of entrepreneurs both inside and outside the corporation to organize for innovation.

\section{Coda}

Perhaps now it is time to pass the baton back to Mr. Lee. After the terrible year Samsung has had with both smartphone failure and the government corruption hearings, in which Jay M. Lee, Mr. Lee's son and successor as Samsung CEO has been Exhibit One, the Korean Press must recognize that there is no need to import foreign "experts on failure." Still, there may be something for us to ponder from Samsung's misfortune. It is hard to argue with the company's success since that long-ago strategic planning session in 1988. The company surpassed its goal to be one of the world's top five electronics companies. It now ranks among the world's largest companies, right up there with Apple and Google. Ironically, its huge size relative to the South Korean economy over all, and its great international success in electronics, especially recently in smartphones, may have been its undoing. 
In the case of its smartphone debacle, South Korean regulators, who appear to have been accustomed to deferring to the company, may have allowed it to ship phones that did not meet safety standards. When we consider the American companies that are now grouped with Samsung as the world's largest, we can see that the U.S. Justice Department, quiescent since the 1980s on the subject of antimonopoly, has allowed these companies to grow to such a size and value that they may not be a large part of the U.S. GDP, but they do represent a big chunk of U.S. stock indices. In this case, it may not be prosecution, but the failure to prosecute, that has unintended consequences for them. They are buying up many independent smaller technology companies that would otherwise grow on their own. Moreover, their very importance to the U.S. stock market may, in a perverse way, make it harder for them to innovate in the way they clearly intend to do. ${ }^{66}$ Despite its strenuous efforts to preserve the right to manage for the long term, it is hard to see how Google's shareholders can tolerate a failure with a "Moonshot." Nor is it likely that Apple can take a chance with a serious follow-up to iPhone when they account for so large a segment of institutional holdings. The financialization of intellectual property has also become a major issue. Apple's controversial tax-avoidance practices are said to hinge on its ability to run its vast licensing income though shell companies in Ireland. The risk, in other words, is not just to the companies and their shareholders but also to the U.S. economy. Time for another TNEC?

\section{Bibliography of Works Cited}

\section{Books}

Aitken, Hugh G. J. The Continuous Wave: Technology and American Radio, 1900-1932. Princeton, NJ: Princeton University Press, 1988.

Allison, David K. New Eyes for the Navy: The Origin of Radar and the Naval Research Laboratory. Washington, DC: Naval Research Laboratory, 1981.

Bilby, Kenneth. The General: David Sarnoff and the Rise of the Communications Industry. New York: HarperCollins, 1986.

Buderi, Robert. The Invention That Changed the World: How a Small Group of Radar Pioneers Won the Second World War and Launched a Technical Revolution. New York: Simon and Schuster, 1996.

Chandler, Alfred D., Jr. Inventing the Electronic Century: The Epic Story of the Consumer Electronics and Computer Industries. Cambridge, MA: Harvard University Press, 2001.

66. See Mary O'Sullivan's convincing argument along these lines in Contests for Corporate Control. 
- Scale and Scope: The Dynamics of Industrial Capitalism. Cambridge, MA: Harvard University Press, 1990.

. The Visible Hand: The Managerial Revolution in American Business. Boston, MA: Harvard University Press, 1977.

Clark, Walter. "Charles Edward Kenneth Mees, 1882-1960." Royal Society 7 (1961): 173-197.

Dessauer, John H. My Years with Xerox: The Billions Nobody Wanted. New York: Manor Books, 1971.

Ellis, Charles D. Joe Wilson and the Creation of Xerox. Hoboken, NJ: John Wiley \& Sons, 2006.

Florida, Richard, and Martin Kenney. The Breakthrough Illusion: Corporate America's Failure to Move from Innovation to Mass Production. New York: Basic Books, 1990.

Freyer, Tony A. Antitrust and Global Capitalism, 1930-2004. New York: Cambridge University Press, 2006.

- Regulating Big Business: Antitrust in Great Britain and America: 1880-1990. New York: Cambridge University Press, 1992.

Galison, Peter, and Bruce Hevly, ed. Big Science: The Growth of Large-Scale Research. Stanford, CA: Stanford University Press, 1992.

Graham, Margaret B. W., and Bettye H. Pruitt. R\&D for Industry: A Century of Technical Innovation at Alcoa. New York: Cambridge University Press, 1990.

Graham, Margaret B. W. RCA and the VideoDisc: The Business of Research. New York: Cambridge University Press, 1986.

Graham, Margaret B. W., and Alec Shuldiner. Corning and the Craft of Innovation. New York: Oxford University Press, 2001.

Greenstein, Shane. How the Internet Became Commercial: Innovation, Privatization, and the Birth of a New Network. Princeton, NJ: Princeton University Press, 2015.

Hiltzik, Michael A. Dealers of Lightning: Xerox PARC and the Dawn of the Computer Age. New York: HarperCollins, 1999.

Hounshell, David A., and John Kenly Smith. Science and Corporate Strategy: DuPont R\&D, 1902-1980. (Studies in Economic History and Policy: The United States in the Twentieth Century.) Cambridge: Cambridge University Press, 1988.

Jacobson, Gary, and John Hillkirk. Xerox: American Samurai. New York: MacMillan Publishing Company, 1986.

Jenkins, Reese. Images of Enterprise: Technology and the American Photographic Industry 1839-1935. Baltimore, MD: Johns Hopkins University.

John, Richard. Review of The Problem of Remaining Innovative: Insights from Twentieth-Century American Business, by Sally H. Clarke, Naomi R. Lamoreaux, and Steven W. Usselman. Business History Review 85 (Spring 2011): 185-201.

—. "Patents and Free Enterprise: The TNEC Reconsidered." Paper presented at the Annual History of Business History Conference, Portland, OR, March 31-April 2, 2016.

Kearns, David D., and David A. Nadler. Prophets in the Dark: How Xerox Reinvented Itself and Beat Back the Japanese. New York: Harper Business, 1992. 
Kevles, Daniel J. The Physicists: The History of a Scientific Community in Modern America, New York: Alfred A. Knopf, 1978.

Koistinen, Paul A. C. Arsenal of World War II: The Political Economy of American Warfare, 1940-1945. Lawrence: University Press of Kansas, 2004.

Lécuyer, Christophe. Making Silicon Valley: Innovation and the Growth of High Tech, 1930-1970. Cambridge, MA: MIT Press, 2006.

Mowery, David C., and Nathan Rosenberg. Technology and the Pursuit of American Growth. Cambridge: Press Syndicate, 1989.

O'Sullivan, Mary A. Contests for Corporate Control: Corporate Governance and Economic Performance in the United States and Germany. Oxford: Oxford University of Press, 2000.

Owen, David. Copies in Seconds: Chester Carlson and the Birth of the Xerox Machine. New York: Simon \& Schuster, 2004.

Pruitt, Bettye H. Timken: From Missouri to Mars-A Century of Leadership in Manufacturing. Boston: Harvard Business Review Press, 1998.

Pursell, Carroll W. Jr., ed. Technology in America: A History of Individuals and Ideas. Cambridge, MA: MIT Press, 1981.

Radio Corporation of America, Laboratories Division. 1967. 1942-1967: Twenty-Five Years at RCA Laboratories. Philadelphia: Smith Edwards Co. www.worldcat.org/title/1942-1967-twenty-five-years-at-rca-laboratories/ oclc/8264045

Reich, Leonard S. The Making of American Industrial Research: Science and Business at GE and Bell, 1876-1926. Cambridge: Cambridge University Press, 1985.

Roland, Alex. The Military-Industrial Complex. Washington, DC: American Historical Association, 2001.

Rosenberg, Nathan. Exploring the Black Box: Technology, Economics, and History. Cambridge: Cambridge University Press, 1994.

Rosenbloom, Richard S., and William J. Spencer, eds. Engines of Innovation: Industrial Research at the End of an Era. Boston: Harvard Business School Press, 1996.

Sparrow, James T. Warfare State: World War II Americans and the Age of Big Government. New York: Oxford University Press, 2011.

Wells, Wyatt. Antitrust and the Formation of the Postwar World. New York: Columbia University Press, 2002.

\section{Articles, Chapters in Books, and Presentations}

Adams, Stephen B. "Stanford University and Frederick Terman's Blueprint for Innovation in the Knowledge Economy." In The Challenge of Remaining Innovative, edited by Sally H. Clarke, Naomi R. Lamoreaux, and Stephen W. Usselman, 169-190. Stanford, CA: Stanford University Press, 2009.

Chesbrough, Henry. "Graceful Exits and Missed Opportunities: Xerox's Management of its Technology Spin-Off Organizations." Business History Review 76, no. 4 (2002): 803-837.

Davis, L. J. "Did RCA Have to Be Sold?” New York Times, September 20, 1987. 
Fortune Magazine. "Brain Trusts: America’s Greatest Corporate Research Labs," December 8, 1997.

Gladwell, Malcolm. "Creation Myth: Xerox, PARC, Apple, and the Truth about Innovation." The New Yorker, May 16, 2011.

Graham, Margaret B. W. "Financing Fiber: Corning's Invasion of the Telecommunications Market." In Financing Innovation in the United States 1870 to the Present, edited by Lamoreaux, Naomi R. and Kenneth L. Sokoloff, 247-281. Cambridge, MA: Massachusetts Institute of Technology.

. "Industrial Research in the Age of Big Science." Vol. 2 of Research on Technological Innovation, Management and Policy, edited by Richard S. Rosenbloom, 47-80. Greenwich: Jai Press Inc., 1985.

—. "Intellectual Property and the Professionals." History and Technology: An International Journal 28, no. 1 (April 2012): 73-82.

—. "When Industrial R\&D Became Corporate." Paper presented at the History of Capitalism 2.0, Cornell University, Ithaca, New York, September 20-October 1, 2016.

—. "The Transformation of Corporate Research." Technology in Society 7, no. 2-3 (1985): 179-195.

Hart, David M. "Antitrust and Technological Innovation in the U.S.: Ideas, Institutions, Decisions and Impacts, 1890-2000." Research Policy 30, no. 6 (June 2001): 923-936.

Hounshell, David A. "DuPont and the Management of Large-Scale Research and Development." In Big Science: The Growth of Large-Scale Research, edited by Peter Galison and Bruce Hevly, 236-261. Stanford, CA: Stanford University Press, 1992.

—. "The Evolution of Industrial Research in the United States." In Engines of Innovation: Industrial Research at the End of an Era, edited by Richard S. Rosenbloom and William J. Spencer, 13-85. Boston: Harvard Business School Press, 1996.

Kline, Ronald R., and Thomas C. Lassman. "Competing Research Traditions in American Industry: Uncertain Alliances between Engineering and Science at Westinghouse Electric, 1886-1935.” Enterprise \& Society 6, no. 4 (2005): 601-645.

Lamoreaux, Naomi R., Kenneth L. Sokoloff, and Dhanoos Suttiphisal. "The Reorganization of Inventive Activity in the United States during the Early Twentieth Century." In Understanding Long-Run Economic Growth: Geography, Institutions and the Knowledge Economy, edited by Dora L. Costa and Naomi R. Lamoreaux, chapter 8. Chicago: University of Chicago, 2011.

Leslie, Stuart W., and Robert H. Kargon. "Electronics and the Geography of Innovation in Post-War America.” History and Technology 11, no. 2 (1994): 217-231.

Lipartito, Kenneth. "The Antimonopoly Tradition." University of St. Thomas Law Journal 10, no. 4 (Spring 2013): 991-1012.

— . "Picturephone and the Information Age: The Social Meaning of Failure." Technology and Society 44, no. 1 (January 2003): 50-81.

. "Rethinking the Invention Factory: Bell Laboratories in Perspective." In The Challenge of Remaining Innovative: Insights from Twentieth-Century 
American Business, edited by Sally H. Clarke, Naomi R. Lamoreaux, and Stephen W. Usselman, pp. 132-162. Stanford, CA: Stanford University Press, 2009.

Review of After the Breakup: Assessing the New Post-AT\&T Divestiture Era, edited by Barry G. Cole. Business History Review 66, no. 1 (1992): 199-201.

Lipartito, Kenneth, and Paul J. Miranti. "Professions and Organizations in 20th Century America." Social Science Quarterly 79, no. 2 (1998): 301-320.

Myers, Mark. "Research and Change Management in Xerox." In Engines of Innovation: Industrial Research at the End of an Era, edited by Richard S. Rosenbloom and William J. Spencer, 1-12. Boston: Harvard Business School Press, 1996.

Nishimura, Shigehiro. "Measuring Innovation: What Do Patent Statistics Represent?" Paper presented at the Annual History of Business History Conference, Portland, OR, March 31-April 2, 2016.

Posner, Richard A. "Values and Consequences: An Introduction to the Economic Analysis of Law." Coase-Sandor Institute for Law and Economics, Working Paper No. 53, University of Chicago Law School, 1998.

Ranganath, Nayak P., and John M. Ketteringham. "JVC and the VCR." In Breakthroughs: How Leadership and Drive Create Commercial Innovations and Sweep the World, chapter 2. San Diego: Mercury, 1993.

Reich, Leonard S. "Lighting the Path to Profit: GE's Control of the Electric Lamp Industry, 1892-1941.” Business History Review 66, no. 2 (June 1992): 305-334.

Sang-Hun, Choe, and Paul Mozur. "Samsung Galaxy Note 7 Crisis Signals Problems at Korea, Inc.” New York Times, January 23, 2017.

Schweber, S. S. "Big Science in Context: Cornell and MIT.” In Big Science: The Growth of Large-Scale Research, edited by Peter Galison and Bruce Hevly, 149-183. Stanford, CA: Stanford University Press, 1992.

Smith, Douglas, and Robert C. Alexander. Fumbling the Future: How Xerox Invented, then Ignored, the First Personal Computer. Lincoln, NE: toExcel.

Waller, Spencer Weber. "The Antitrust Legacy of Thurman Arnold." St. John's Law Review 78, no. 3 (Summer 2004): 569-613.

Wang, Jessica. "Science, Security, and the Cold War: The Case of E.U. Condon." Isis 83, no. 2 (June 1992): 238-269.

Wilson, Mark R. Book review, "Warfare State: World War II Americans and the Age of Big Government," by James T. Sparrow. Enterprise and Society 16, no. 3 (September 2015): 696-697 